\title{
REKONSTRUKSI EKSISTENSI BALAI HARTA PENINGGALAN SEBAGAI WALI PENGAWAS MELALUI HARMONISASI PERATURAN HUKUM TENTANG PERWALIAN
}

\section{(EXISTENCE RECONSTRUCTION OF PROBATE COURT AS TRUSTEE OVERSEER THROUGH HARMONIZATION OF REGULATIONS ON TRUSTEESHIP)}

\author{
Oleh: Shela Natasha \\ Balai Harta Peninggalan Medan \\ (UPT Kanwil Kemenkumham Sumatera Utara) \\ Email: shelanatasha13@gmail.com
}

\begin{abstract}
ABSTRAK
Harmonisasi Peraturan perundang-undangan merupakan salah satu komponen terpenting untuk mendorong proses pembangunan hukum dalam rangka mewujudkan konsep negara hukum yang baik di Indonesia. Peraturan perundang-undangan di Indonesia di bidang perwalian, khususnya mengenai wali pengawas sampai saat ini masih belum mampu memberikan sumbangsih yang besar dalam pembangunan hukum di Indonesia karena antara peraturan perundang-undangan di bidang perwalian yang satu dengan lainnya masih terjadi disharmonisasi, tumpang tindih, benturan asas, dan pertentangan satu sama lain yang menyebabkan kurang jelasnya eksistensi dan peran Balai Harta Peninggalan sebagai wali pengawas dalam perwalian, padahal wali pengawas berperan penting dalam menjamin keberlangsungan pemenuhan hak-hak keperdataan anak yang berada di bawah perwalian. Oleh karena itu, dilakukan sebuah penelitian dengan sifat deskriptif dan pendekatan yuridis empiris yang mengkaji ketentuan hukum yang berlaku dan apa yang tengah terjadi di masyarakat, sehingga diketahui bahwa perlu dilakukan rekonstruksi pemikiran tentang eksistensi Balai Harta Peninggalan sebagai wali pengawas melalui harmonisasi Peraturan perundang-undangan di bidang perwalian sehingga kedepannya kesejahteraan anak yang berada di bawah perwalian dapat terjamin.
\end{abstract}

Kata Kunci: Harmonisasi, Perwalian, Balai Harta Peninggalan, Wali Pengawas

\begin{abstract}
Harmonization of regulation is the most important component to urge the process of legal development in order to manifest the good concept of Rule of Law in Indonesia. Regulations in Indonesia on trusteeship, especially about trustee overseer still not able to give a big contribution to legal development in Indonesia because disharmony, overlapping, principle conflicts, and contradiction still occurs between one and the other regulations which make Probate Court's role and existence as trustee overseer on trusteeship unclear, even though trustee overseer has an important role to ensure civil right fulfillment of trusteeship's children. Therefore, a research conducted by the descriptive quality and empirical judicial approach that review an exist legal provision and what is happening in community so that reconstruction about Probate Court's existence as a trustee overseer by harmonization of regulations on trusteeship should be done so that the welfare of trusteeship's children can be guaranteed.
\end{abstract}

Keywords: Harmonization, Trusteeship, Probate Court, Trustee Overseer 


\section{A. Pendahuluan}

Indonesia telah dikenal oleh berbagai negara lain di belahan dunia sebagai lahan subur dengan Sumber Daya Alam (SDA) melimpah, namun mirisnya pengelolaan SDA yang melimpah tersebut masih belum maksimal karena potensi Sumber Daya Manusia (SDM) masih belum dimaksimalkan. Untuk mengatasi permasalahan keterbatasan potensi SDM sebagaimana disinggung di atas, pemerintah terlihat berusaha hadir dalam membimbing anak-anak bangsa yang merupakan tunas dan generasi penerus untuk menjadi SDM yang cerdas, berdaya saing tinggi, berakhlak mulia, serta memiliki nasionalisme yang tinggi.

Berdasarkan Pasal 45 ayat (1) jo. Pasal 45 ayat (2) Undang-Undang Nomor 1 Tahun 1974 tentang Perkawinan (UU Perkawinan), orang tua wajib memelihara dan mendidik anak-anak mereka sebaik-baiknya sampai anak itu kawin atau berdiri sendiri dan kewajiban tersebut berlaku terus meskipun perkawinan antara kedua orang tua putus. Namun kenyataannya masih ada orang tua yang menelantarkan anak-anaknya. ${ }^{1}$ Anak merupakan aset bangsa yang harus diproteksi dari segala macam ancaman, baik materil maupun immateril yang dapat mempengaruhi kehidupannya di masa depan, karena apabila aset bangsa tersebut tidak dilindungi maka akan pupus harapan negara untuk memperoleh SDM berkualitas di masa depan kelak.

Pada umumnya anak yang masih berada di bawah umur tidak dapat melakukan pemenuhan haknya seorang diri, sehingga anak membutuhkan perlindungan dan pertolongan dari orang dewasa, khususnya orang tua. Dalam Pasal 20 UU Perlindungan Anak disebutkan bahwa "Negara, pemerintah, masyarakat, keluarga, dan orang tua berkewajiban dan bertanggung jawab terhadap penyelenggaraan perlindungan anak. Wujud keseriusan pemerintah dalam melindungi anak yang dianggap sebagai aset bangsa terlihat dalam konstitusi yang menjamin bahwa setiap anak berhak atas kelangsungan hidup, tumbuh dan berkembang serta berhak atas

1 Di Makassar, seorang ibu berinisial MR alias MM ditetapkan sebagai tersangka dari kasus penelantaran terhadap anak kandungnya. Tersangka disangkakan Pasal 77, 76, dan 80 Undang-undang Nomor 17 Tahun 2016 tentang Perlindungan Anak. Serta Pasal 44 Undang-undang Nomor 23 Tahun 2004 tentang Kekerasan Dalam Rumah Tangga. Lihat: https://news.okezone.com/read/2018/09/18/340/1952183 /ibu-penyekap-3-bocah-di-makassar-ditetapkan-sebagai-tersangka 
perlindungan dari kekerasan dan diskriminasi. Sebagai tindak lanjut dari konstitusi, dikeluarkanlah berbagai instrumen Peraturan perundang-undangan yang ditujukan untuk menjamin perlindungan pada anak, baik yang pengaturannya bersifat khusus seperti Undang-Undang Nomor 35 Tahun 2014 tentang Perlindungan Anak, maupun yang lebih umum seperti Undang-Undang Nomor 1 Tahun 1974 tentang Perkawinan yang beberapa pasalnya mengatur tentang hak-hak seorang anak.

Setiap orang tua pada dasarnya akan berusaha memenuhi kebutuhan sang anak baik dari sisi materil maupun immateril, namun terkadang terdapat kondisi tertentu yang menyebabkan seorang anak harus berada dalam perwalian, yakni kondisi dimana anak yang belum mencapai usia 18 tahun atau belum menikah, berada di bawah kekuasaan wali dimana wali tersebut mengatur hal-hal terkait mengenai pribadi anak yang bersangkutan maupun harta bendanya. Seorang anak dapat berada di bawah perwalian apabila salah satu atau kedua orang tua sang anak telah meninggal dunia, orang tua si anak telah bercerai, atau apabila orang tua si anak dicabut kekuasaannya sebagai orang tua oleh penetapan pengadilan. Pencabutan kekuasaan orang tua terhadap anaknya terjadi dalam hal orang tersebut melalaikan kewajibannya terhadap anaknya atau ia berkelakuan buruk sekali. ${ }^{2}$ Penunjukan wali dilakukan oleh hakim di pengadilan dengan memperhatikan terlebih dahulu kerabat terdekat sang anak yang dapat ditunjuk menjadi wali. Seorang wali diberikan kewenangan untuk mengatur dan mengurus anak dan harta kekayaan anak yang berada di bawah perwaliannya. Kewenangan yang diberikan kepada seorang wali harus disertai pula dengan pengawasan terhadap pelaksanaan kewenangan tersebut agar kewenangan yang dimiliki tidak dijalankan secara sewenang-wenang. Segala bentuk kemungkinan penyalahgunaan kewenangan pada umumnya harus dicegah untuk meminimalisir terjadinya penyalahgunaan, sehingga dalam hal ini negara telah memberikan jaminan perlindungan terhadap tiap-tiap anak yang berada di bawah perwalian dengan menunjuk Balai Harta Peninggalan, sebuah instansi yanng

2 Nathalia Jesica Djumati, Penentuan Hak Perwalian Anak Akibat Perceraian Menurut Undang-Undang Nomor 1 Tahun 1974 Tentang Perkawinan. Jurnal Lex Privatum Vol. VI/No. 4/Jun/2018 (2018): 40 
didirikan pada tanggal 1 Oktober 1624 oleh pemerintahan Belanda yang pada saat itu berkuasa di Batavia. $^{3}$ Balai Harta Peninggalan secara struktur organisasi berada di bawah naungan Kementerian Hukum dan Hak Asasi Manusia tepatnya di bawah Direktorat Perdata Ditjen Administrasi Hukum Umum, untuk menjadi wali pengawas dalam urusan perwalian sebagaimana diamanatkan dalam ketentuan Pasal 366 KUHPerdata.

Segera setelah adanya penetapan perwalian dari Pengadilan Negeri, Balai Harta Peninggalan selaku wali pengawas harus mendapatkan pemberitahuan secara tertulis dari Panitera Pengadilan Negeri sebagaimana yang disebutkan dalam Pasal 369 KUHPerdata sehingga Balai Harta Peninggalan dapat mulai melaksanakan tugasnya sebagai wali pengawas. Wali pengawas merupakan pihak yang diberikan kewajiban oleh Pasal 370 KUHPerdata untuk mewakili kepentingan anak yang berada di bawah perwalian, dalam hal menjamin bahwa segala hak-hak keperdataan dan harta peninggalan anak yang berada di bawah perwalian dijaga dan memang dipergunakan oleh wali untuk kepentingan anak.

Tugas dan kewajiban wali pengawas dijabarkan secara umum dalam pasal-pasal di KUHPerdata, khususnya dalam pasal yang menjabarkan tentang perwalian, akan tetapi di dalam peraturan perundangundangan lain, peran Balai Harta Peninggalan seolah-olah dikikis karena minimnya aturan perundang-undangan yang menjelaskan peran Balai Harta Peninggalan sebagai wali pengawas. Belakangan, lahir Peraturan Pemerintah Nomor 29 Tahun 2019 tentang Syarat dan Tata Cara Penunjukan Wali yang menjabarkan di Pasal 25 dan Pasal 26 bahwa pengawasan terhadap wali dan urusan perwalian dilakukan oleh pemerintah, dalam hal ini adalah pemerintah yang menyelenggarakan urusan sosial yang mengakibatkan abrasi kewenangan pada Balai Harta Peninggalan. Jenis dan hierarki peraturan perundang-undangan di Indonesia telah mengalami pasang surut sesuai dengan perubahan dan perkembangan konstitusi serta peraturan perundang-undangan yang

3 Syuhada, Analisis Hukum Terhadap Kewenangan Balai Harta Peninggalan Dalam Pengelolaan Harta Kekayaan Yang Tidak Diketahui Pemilik dan Ahliwarisnya (Studi di Balai Harta Peninggalan Medan), Tesis, Universitas Sumatera Utara, Medan, 2009, hlm. 116 
berlaku di Indonesia ${ }^{4}$, dimulai dari TAP MPRS No. XX/MPRS/1966 hingga perubahan yang terakhir yaitu Undang-Undang Nomor 12 Tahun 2011 tentang Pembentukan Peraturan Perundangundangan. Tata urutan peraturan perundang-undangan di Indonesia banyak mendapatkan pengaruh dari pemikiran Hans Kelsen (stufentheorie) dan Hans Nawiasky (die theorie vom stufentordnung der rechtsnormen), sebagaimana yang diungkapkan oleh A. Hamid S. Attamimi ${ }^{5}$ dalam disertasinya. Asean Law Association ${ }^{6}$ mengemukakan bahwa "...Both theories suggest that the legal norm is always structured in tiers and is hierarchical in nature, particularly that the lower norm is based on the higher norm until the point where it meets the highest norm which then becomes the basic norm "

Berbagai perubahan yang terjadi pada hierarki peraturan perundang-undangan di Indonesia tak lepas kaitannya dari keinginan pemerintah untuk mewujudkan suatu pembangunan hukum nasional yang dilakukan secara terencana, terpadu, dan berkelanjutan, serta tetap sesuai dengan nilai-nilai yang terkandung di dalam Pancasila sebagai sumber dari segala sumber hukum yang menjiwai setiap peraturan perundang-undangan di Indonesia, karena salah satu tiang utama dalam penyelenggaraan pemerintahan suatu negara adalah pembentukan peraturan perundang-undangan yang baik, harmonis, dan mudah diterapkan dalam masyarakat. $^{7}$ Pembangunan hukum nasional yang terarah hanya dapat terwujud apabila peraturan perundangundangan tersusun secara hierarkis, sehingga jelas mana aturan hukum yang menjadi grundnorm bagi aturan hukum lain, serta aturan hukum mana yang lebih tinggi dari aturan hukum yang lainnya. Wujud normatif hierarki peraturan perundang-undangan yang berlaku di Indonesia dapat ditelusuri melalui Pasal 7 Undang-Undang Pembentukan Peraturan

4 Riki Yuniagara, Jenis dan Hirarki Peraturan Perundang-Undangan Indonesia Dalam Lintas Sejarah (TAP MPR dari Masa ke Masa), (Aceh: Unknown,2013), hlm. 3

5 A. Hamid S. Attamimi, Peranan Keputusan Presiden Republik Indonesia dalam Penyelenggaraan Pemerintahan Negara: Suatu Studi Analisis Mengenai Keputusan Presiden yang Berfungsi Pengaturan dalam Kurun Waktu Pelita I-Pelita IV, Disertasi, (Jakarta: Pascasarjana Universitas Indonesia, 1990), hlm.287

6 Asean Law Association, Indonesian Legal System, Editor: Hikmahanto Juwana, et.al., (Philippines: Asean Law Association, 2005), hlm. 17

7 Maria Farida Indrarti Soeprapto, Ilmu Perundang-undangan 2, (Yogyakarta: Kanisius, 2007), hlm. 1 
Perundang-undangan yang mengatur bahwa jenis dan tata urutan peraturan perundang-undangan di Indonesia terdiri dari UUD 1945, Tap MPR, UU/Perppu, PP, Peraturan Presiden, Peraturan Daerah (Provinsi dan Kabupaten/Kota).

Merujuk dari Hierarki Peraturan Perundang-undangan, Peraturan Pemerintah Nomor 29 Tahun 2019 tidak seharusnya mengesampingkan ketentuan KUHPerdata dan Undang-Undang Perlindungan Anak, karena secara tidak langsung telah mengikis eksistensi (abrasi kewenangan) Balai Harta Peninggalan yang ditugaskan oleh KUHPerdata sebagai wali pengawas, sehingga diperlukan pembahasan lebih lanjut mengenai rekonstruksi eksistensi Balai Harta Peninggalan sebagai wali pengawas dengan cara mengharmonisasikan segala bentuk peraturan perundang-undangan di bidang perwalian.

\section{B. Metode Penelitian}

Di dalam penulisan ini jenis penelitian yang dipilih adalah penelitian deskriptif, yakni suatu penelitian yang dimaksudkan untuk memberikan dan menggambarkan data yang seteliti mungkin tentang manusia, keadaan atau gejala-gejala lainnya. Penelitian ini diharapkan dapat mendeskripsikan tentang pentingnya menjaga eksistensi dan stabilitas peran Balai Harta Peninggalan sebagai wali pengawas dengan cara mengharmonisasikan segala bentuk peraturan perundang-undangan di bidang perwalian.

Penelitian ini menggunakan pendekatan yang bersifat yuridis empiris. Penelitian hukum empiris bertujuan untuk mengkaji ketentuan hukum yang berlaku serta apa yang terjadi dalam kenyataannya di masyarakat. ${ }^{8}$ Dalam menganalisis data yang diperoleh, penulis menggunakan teknik analisis isi (content analysis), yaitu suatu analisis terhadap isi data yang diperoleh secara kualitatif.

\section{Pembahasan}

1. Rekonstruksi Eksistensi Balai Harta Peninggalan dalam Perwalian

Secara etimologi (bahasa), kata perwalian berasal dari kata wali, dan jamak awliya. Kata ini berasal dari kata Arab yang berarti teman, klien, sanak atau pelindung. Dalam literatur fiqih islam perwalian itu disebut dengan " $A$ I-

8 Bambang Waluyo, Penelitian Hukum Dalam Praktek, (Jakarta: Sinar Grafika, 2002), hlm. 15 
Walayah" (Orang yang mengurus atau yang menguasai sesuatu), sedangkan al-wali yakni orang yang mempunyai kekuasaan. $^{9} \quad$ Menurut Subekti, perwalian (voogdig) adalah pengawasan terhadap anak di bawah umur, yang tidak berada di bawah kekuasaan orang tua serta pengurusan benda atau kekayaan anak tersebut diatur oleh undang-undang. ${ }^{10}$

\begin{tabular}{lrr}
\multicolumn{1}{c}{ Ruang } & lingkup & perwalian \\
berdasarkan & Pasal 383 & ayat (1) \\
KUHPerdata & meliputi & melaksanakan \\
pemeliharaan & dan & pendidikan \\
terhadap & anak & dengan
\end{tabular}
mempergunakan harta peninggalan kekayaannya dan dapat mewakili dalam segala tindakan atas nama anak. Yang dimaksud anak dalam ketentuan tersebut ialah mereka yang belum dewasa, di mana dalam Pasal 330 KUHPerdata disebutkan yang dimaksud belum dewasa ialah "mereka yang belum mencapai umur genap dua puluh satu tahun, dan tidak lebih dahulu telah kawin". ${ }^{11}$ Kategori anak yang masuk dalam lingkup perwalian ialah:

a. Anak sah yang kedua orang tuanya telah dicabut kekuasaannya sebagai orang tua;

b. Anak sah yang orang tuanya telah bercerai;

c. Anak yang lahir di luar perkawinan (natuurlijk kind). ${ }^{12}$

Dalam perwalian, pihak yang menjadi sorotan adalah wali selaku pihak yang memiliki hak untuk menjalankan perwalian. Menurut KUHPerdata, pihak-pihak yang dapat menjadi wali antara lain:

a. Suami atau istri yang hidup lebih lama atau langstlevendeechtgenoot (Pasal 345 - Pasal 354 KUHPerdata) Apabila salah satu dari kedua orang tua meninggal dunia, maka perwalian terhadap anak-anak yang belum dewasa demi hukum dipangku oleh orang tua yang hidup terlama. Pasal ini

9 Muhammad Amin Summa, Hukum Keluarga Islam Dikeluarga Islam, (Jakarta: PT Raja Grafindo, 2001), hlm. 134.

10 R. Subekti, Pokok-Pokok Hukum Perdata, (Jakarta: Intermasa, 2001), hlm. 52.

11 Yulita Dwi Pratiwi, Harmonisasi Perlindungan Harta Kekayaan Anak dalam Perwalian melalui Penguatan Peran Wali Pengawas, Jurnal Suara Hukum Volume 1 Nomor 1, Maret (2019): 66

12 Septy Veronita, Hak Perwalian Anak di Bawah Umur yang Beralih pada Neneknya (Analisis kasus Putusan Mahkamah Agung Republik Indonesia Nomor:372K/Pdt/2008, Tesis, (Jakarta: Universitas Indonesia, 2013), hlm. 53 
tidak membuat pengecualian bagi

suami istri yang hidup terpisah

disebabkan oleh perceraian, sehingga apabila ayah yang menjadi wali setelah perceraian, maka jika ayah meninggal maka ibu yang dengan sendirinya (demi hukum) menjadi wali atas anak tersebut. ${ }^{13}$

b. Pihak yang ditunjuk oleh orang tua dengan surat wasiat atau akta tersendiri (Pasal 355 ayat (1) KUHPerdata)

Masing-masing orang tua yang melakukan perwalian atas seorang anak atau lebih berhak mengangkat seorang wali atas anak-anak tersebut melalui wasiat ataupun akta tersendiri, sehingga ketika ia telah meninggal dunia, telah ada wali yang ditunjuk melalui wasiat yang bersangkutan.

c. Pihak yang diangkat oleh Hakim (Pasal 359 KUHPerdata)

Anak-anak yang belum dewasa yang tidak berada di bawah kekuasaan orang tua dan yang diatur perwaliannya secara sah, akan ditunjuk seorang wali oleh Pengadilan. Hakim akan mengangkat seorang wali setelah mendengar atau memanggil keluarga sedarah (bloedverwanten) atau semenda atau periparan (aangehuwden). ${ }^{14}$

Segera setelah sah secara hukum menjadi seorang wali, maka wali akan mengemban kewajiban-kewajiban keperdataan sebagai berikut:

a. Memberitahukan kepada Balai Harta Peninggalan bahwa telah berlangsung suatu perwalian (Pasal 368 KUHPerdata);

b. Menyelenggarakan pengurusan harta kekayaan anak di bawah umur itu dengan baik sesuai dengan ketentuan undang-undang (Pasal 371 KUHPerdata);

c. Mengadakan inventarisasi mengenai harta si anak yang berada di bawah perwaliannya (Pasal 386 ayat (1) KUHPerdata);

d. Membuat suatu ikatan jaminan, hipotek, gadai, atau menambah jaminan yang telah ada dalam hal harta anak yang berada di bawah

Ibid., hlm. 58

14 Ibid., hlm. 59 
perwalian semakin bertambah

(Pasal 335 KUHPerdata);

e. Menentukan jumlah yang dapat dipergunakan tiap-tiap tahun oleh anak tersebut dan biaya pengurusan $\quad$ (Pasal 338 KUHPerdata);

f. Mendaftarkan surat-surat piutang negara jika ternyata dalam harta kekayaan si anak terdapat surat piutang negara (Pasal 392 KUHPerdata);

g. Mengajukan surat permohonan penjualan harta kekayaan anak yang berada di bawah perwalian kepada Pengadilan Negeri (Pasal 394 KUHPerdata);

h. Memberikan perhitungan dan tanggung jawab atas pengurusan yang sudah dilakukan (Pasal 373 jo. Pasal 409 KUHPerdata).

Perbuatan hukum yang dilakukan wali bukanlah penguasan mutlak yang tanpa batasan saat menjalan perwalian. Wali dapat dipecat bahkan mengganti kerugian apabila melakukan tindakan yang dianggap merugikan bagi anak. Syarat utama pemecatan wali didasarkan atas kepentingan anak itu sendiri. Alasan lain sebagai dasar memintakan pemecatan atas wali diuraikan dalam KUHPerdata, yang dirangkum sebagai berikut:

a. Jika wali berkelakuan buruk;

b. Jika dalam melaksanakan tugasnya wali tidak cakap atau menyalagunakan kecakapannya;

c. Jika wali dalam keadaan pailit;

d. Jika wali untuk dirinya sendiri atau keluarganya melakukan perlawanan terhadap si anak tersebut;

e. Jika wali dijatuhi hukuman pidana yang telah berkekuatan hukum tetap;

f. Jika wali alpa memberitahukan terjadinya perwalian kepada Balai Harta Peninggalan;

g. Jika wali tidak memberikan pertanggungjawaban kepada Balai Harta Peninggalan. ${ }^{15}$

Untuk mencegah penyimpangan ataupun pelanggaran dalam perwalian, khususnya penyimpangan dalam penggunaan harta kekayaan si anak, peraturan perundang-undangan telah

15 R. Soetojo Prawidohamidjojo dan Marthalena Pohan, Hukum Orang dan Keluarga (Personen en FamilieRecht), (Surabaya: Airlangga University Press, 2008), hlm. 231 
mengatur mengenai peran Wali

Pengawas, yakni pihak yang mengawasi keberlangsungan

perwalian terhadap seorang anak. Wali Pengawas berperan untuk menjaga agar wali mempergunakan harta kekayaan anak yang berada di bawah perwalian digunakan untuk kepentingan dari anak yang bersangkutan, bukannya dipergunakan untuk kepentingan pribadi wali. Pasal 366 KUHPerdata jo. Pasal 35 UndangUndang Nomor 23 Tahun 2002 tentang Perlindungan Anak menyebutkan bahwa pihak yang diberikan wewenang oleh undang-undang untuk bertindak sebagai wali pengawas dalam hal adanya perwalian adalah Balai Harta Peninggalan.

$$
\text { Balai Harta Peninggalan }
$$
merupakan salah satu Unit Pelaksana Teknis yang secara sruktural berada di bawah Direktorat Perdata, Direktorat Administrasi Hukum Umum, Kementerian Hukum dan Hak Asasi Manusia Republik Indonesia yang memiliki tugas pokok dan fungsi di bidang keperdataan. Balai Harta Peninggalan pada zaman penjajahan Belanda dikenal dengan nama "Weesen Boedelkamer" atau "Weeskamer", yang dibentuk pertama kali berkedudukan di Jakarta, pada tanggal 1 Oktober 1624. Balai Harta Peninggalan dibentuk untuk memenuhi kebutuhan anggota VOC (Vereenigde Oost Indische Compagnie) khusus dalam mengurus harta kekayaan yang ditinggalkan oleh mereka bagi mereka para ahli waris yang berada di Nederland, anak-anak yatim piatu dan sebagainya. ${ }^{16}$

Sejak Indonesia masih berada di bawah jajahan Belanda hingga sekarang, Balai Harta Peninggalan tetap menjalankan tugas pokok dan fungsi di bidang keperdataan yang pada hakikatnya dapat dibagi menjadi 4 (empat) klasifikasi, yaitu sebagai berikut:

a. Pengampu bagi yang tidak cakap bertindak di bidang hak milik, yaitu:

16 Taufik H. Simatupang, Eksistensi dan Efektivitas Pelaksanaan Tugas Balai Harta Peninggalan di Indonesia (Existence and Effectiveness of Performance of Probate Court Duties in Indonesia), Jurnal Penelitian Hukum De Jure, ISSN 1410-5632 Vol. 18 No. 3, September (2018): 404 
1) Melindungi kepentingan anak di bawah umur;

2) Pengampu Pengawas.

b. Pengelola uang pihak ketiga karena tidak diketahui pemiliknya, yaitu:

1) Uang yang berasal dari orang tidak hadir (afwezigheid);

2) Uang yang berasal dari harta yang tidak terurus (onbeheerde nalatenschappen).

c. Bidang hak waris, yaitu:

1) Membuat surat keterangan hak waris bagi golongan Timur Asing (Surat Menteri Dalam Negeri cq. Kepala Direktorat Pendaftaran Tanah Direktorat Jenderal Agraria Departemen Dalam Negeri tanggal 20 Desember 1969 Nomor: DPT/12/63/12/69 jo. Pasal 111 ayat (1) huruf c Peraturan Kepala Badan Pertanahan Nasional No. 8 Tahun 2012 tentang Ketentuan Pelaksanaan Peraturan Pemerintah
No. 24 Tahun 1997 tentang Pendaftaran Tanah);

2) Mendaftarkan wasiat yang terbuka dan membuka wasiat tertutup.

d. Bidang kepailitan, yaitu:

1) Demi hukum sebagai Kurator Negara;

2) Pengurus Penundaan Kewajiban Pembayaran Utang;

3) Likuidator PT. ${ }^{17}$

Dalam bidang perwalian, tugas Balai Harta Peninggalan sebagai wali pengawas diatur dalam Pasal 366 KUHPerdata yang menyebutkan bahwa dalam tiap-tiap perwalian yang diperintahkan di Indonesia, Balai Harta Peninggalan berkewajiban melaksanakan tugas wali pengawas. Sebagai wali pengawas dalam perwalian, Balai Harta Peninggalan bertindak untuk mengamati apakah wali melaksanakan kewajiban dengan baik atau tidak dan seberapa perlu memberikan nasihat kepada wali untuk melakukan kewajiban dengan sebaikbaiknya. ${ }^{18}$ Adapun peran Balai Harta

17 Ibid., hlm. 405

18 Nurhendro Putranto, Balai Harta Peninggalan Fungsi dan Tugas Pokoknya, Jurnal Ilmiah Balai Harta Peninggalan Surabaya (2013): 16 
Peninggalan dalam melaksanakan tugasnya sebagai wali pengawas dalam perwalian diatur dalam KUHPerdata. Peran Balai Harta Peninggalan sebagai wali pengawas dalam perwalian dapat dijabarkan sebagai berikut:

a. Menyelenggarakan pendaftaran harta kekayaan yang di dalamnya berkepentingan anak belum dewasa (Pasal 127 KUHPerdata);

b. Menyumpah wali dan membuatkan Berita Acara Sumpah (Pasal 362 KUHPerdata);

c. Mewakili kepentingan anak belum dewasa, apabila kepentingan mereka bertentangan dengan walinya (Pasal 370 KUHPerdata);

d. Mengawasi wali untuk membuat pendaftaran harta kekayaan anak (Pasal 370 ayat (2) KUHPerdata);

e. Meminta perhitungan dan tanggungjawab dari wali (Pasal 372 KUHPerdata);

f. Mengajukan usul kepada Pengadilan Negeri untuk memecat wali dan mengajukan calon wali yang baru (Pasal 373 KUHPerdata);

g. Memberi keterangan kepada hakim tentang bermanfaat tidaknya penjualan barang yang didalamnya berkepentingan anak belum dewasa (Pasal 393 KUHPerdata);

h. Mewakili anak belum dewasa melakukan perjanjian sewa menyewa apabila penyewanya adalah wali sendiri (Pasal 400 KUHPerdata);

i. Memberikan kuasa kepada wali untuk bertindak sebagai penggugat maupun tergugat dalam perkara perdata guna kepentingan anak yang belum dewasa (Pasal 403 KUHPerdata);

j. Menghadiri acara pemisahan dan pembagian harta kekayaan yang di dalamnya berkepentingan anak belum dewasa (Pasal 406 KUHPerdata);

Pengangkatan wali pengawas harus selalu terjadi dalam setiap perwalian. Apabila wali tidak memberitahukan kepada Balai Harta Peninggalan tentang terjadinya perwalian, maka wali itu dapat dipecat. R. Soetojo ${ }^{19}$ menguraikan kewajiban

19 R. Soetojo Prawidohamidjojo dan Marthalena Pohan, Op. Cit., hlm. 233 
dari wali pengawas, antara lain sebagai berikut:

a. Mengadakan pengawasan terus terhadap wali;

b. Menyatakan pendapatnya terhadap berbagai tindakan yang harus dilakukan oleh wali atas perintah hakim atau dengan persetujuan hakim;

c. Bertindak bersama-sama dengan wali atau ikut hadir dalam tindakan-tindakan tertentu;

d. Bertindak bila ada kepentingan yang bertentangan antara wali dengan minderjarige (anak yang berada di bawah perwalian); dan

e. Bertindak bila wali tidak hadir atau perwalian itu terluang (terbuka).

Panitera pada pengadilan yang menetapkan adanya suatu perwalian harus segera memberitahukan adanya pengangkatan wali kepada Balai Harta Peninggalan sesuai dengan ketentuan Pasal 369 KUHPerdata. Dengan adanya pemberitahuan tertulis kepada Balai Harta Peninggalan, maka Balai Harta Peninggalan dapat melaksanakan fungsi sebagai wali pengawas. Adapun alur pelaksanaan tugas pokok dan fungsi Balai Harta Peninggalan sebagai wali pengawas adalah sebagai berikut:

a. Balai Harta Peninggalan menunjuk seorang ATH (Anggota Teknis Hukum, yakni pejabat di lingkungan Balai Harta Peninggalan yang memiliki kewenangan untuk melaksanakan tugas pokok dan fungsi di bidang teknis) menjadi wali pengawas.

b. Mengirim surat kepada wali dari anak di bawah umur agar datang ke Balai Harta Peninggalan. Pada saat wali datang ke Balai Harta Peninggalan, selanjutnya akan dibuat Berita Acara Penghadapan. Dalam memberikan keterangan, wali disumpah yang kemudian dituangkan dalam Risalah Penyumpahan.

c. Selanjutnya ATH mendatangi kediaman wali dari anak di bawah umur, menginventarisir jumlah harta anak.

d. ATH memberitahukan kepada wali mengenai tugas, kewajiban dan tanggung jawab wali maupun tugas pokok dan fungsi Balai Harta Peninggalan sebagai wali 
pengawas serta menasehati wali mengenai harta benda milik anak yang harus dipergunakan untuk kepentingan anak dan tidak boleh disalahgunakan.

e. ATH dari Balai Harta Peninggalan mengamankan harta benda hak milik anak dengan cara memblokirnya. Untuk benda tetap berupa tanah pemblokirannya diajukan ke BPN (Badan Pertanahan Nasional). Untuk harta berupa tabungan atau deposito dilakukan pemblokiran ke bank dengan cara mengirim surat kepada Bank tertentu di mana deposito disimpan, agar deposito tidak dapat ditarik tanpa persetujuan Balai Harta Peninggalan. Setelah harta benda hak milik anak diblokir, maka apabila wali mau menjualnya harus mengajukan permohonan ijin lebih dahulu ke Balai Harta Peninggalan. Selanjutnya Balai Harta Peninggalan akan mengeluarkan roya untuk kemudian diajukan ke BPN agar tanah dilepaskan dari pemblokiran.

f. Setiap tahun wali harus memberikan laporan kepada Balai Harta Peninggalan tentang tugas perwalian yang telah dilaksanakannya. ${ }^{20}$

Fungsi Balai Harta Peninggalan sebagai wali pengawas terus dilakukan sampai si anak yang berada di bawah perwalian telah dewasa, yaitu telah berumur 18 tahun.

Ketentuan hukum mengenai keharusan adanya pemberitahuan tertulis tentang terjadinya suatu perwalian kepada Balai Harta Peninggalan tidak senantiasa diindahkan. Seringkali Balai Harta Peninggalan tidak mendapat pemberitahuan mengenai terjadinya suatu perwalian karena masyarakat maupun instansi pemerintahan lainnya masih kurang familiar dengan tugas pokok dan fungsi Balai Harta Peninggalan sebagai wali pengawas. Contohnya saja di Medan, ketika

20 Endang Heriyani dan Prihati Yuniarlin, Fungsi BHP Sebagai Wali Pengawas Terhadap Anak Di Bawah Perwalian Dalam Rangka Perlindungan Anak, Jurnal Media Hukum, Volume 22 No. 2, Desember (2015): 226 
terjadinya peristiwa pembunuhan yang menyebabkan seorang anak bernama Kinara kehilangan orang tua dan saudaranya, Balai Harta Peninggalan Medan tidak dilibatkan secara langsung karena pihak keluarga Kinara pada awalnya tidak memahami konsep perwalian, sehingga Kakek Kinara tidak mengajukan permohonan penetapan wali ke pengadilan yang membawa konsekuensi tidak adanya istilah wali pengawas pada saat itu. Menyadari hal tersebut, Anggota Teknis Hukum di Balai Harta Peninggalan Medan secara aktif memberikan nasehat dan bimbingan agar kakek Kinara mengajukan permohonan penetapan wali ke Pengadilan Agama. Beberapa lama setelah proses persidangan berlangsung, pada akhirnya hakim pada Pengadilan Agama yang memeriksa permohonan perwalian atas Kinara mengeluarkan Penetapan No. 2/Pdt.P/2018/PA.Mdn dan mengabulkan permohonan penetapan Wali dan menetapkan Wagiman bin Dulsamat (Kakek Kinara) menjadi wali atas Kinara Arifah binti Arianto. Selain itu, penetapan pengadilan juga menetapkan Balai Harta Peninggalan Medan selaku wali pengawas atas perwalian Kinara. ${ }^{21}$

Adanya kasus Kinara menggambarkan bahwa Balai Harta Peninggalan Medan menjadi pihak yang aktif dalam memperjuangkan status wali dan wali pengawas, sehingga Balai Harta Peninggalan merupakan pihak utama yang dapat menjadi garda terdepan dalam melindungi hak keperdataan seorang anak yang berada di bawah perwalian. Mengenyampingkan Balai Harta Peninggalan dalam kasus perwalian sama saja dengan menghilangkan pihak yang dapat secara langsung menjamin terpenuhinya hak-hak keperdataan seorang anak yang berada di perwalian. Penguatan eksistensi Balai Harta Peninggalan sebagai wali pengawas perlu dilakukan melalui penegasan tugas dan fungsi Balai Harta Peninggalan sebagai wali pengawas dalam aturan hukum, sehingga terjadi rekonstruksi pemikiran dan cara pandang masyarakat beserta instansi

21 Wawancara dengan Bapak Syuhada selaku Sekretaris Balai Harta Peninggalan Medan pada tanggal 28 Mei 2019 di Kantor Balai Harta Peninggalan Medan 
pemerintahan tentang pentingnya peran Balai Harta Peninggalan pada kasus-kasus perwalian.

\section{Pentingnya Harmonisasi Peraturan} Perundang-Undangan di Bidang

\section{Perwalian}

Legislasi menurut Anis Ibrahim 22 merupakan suatu proses pembuatan hukum dalam rangka melahirkan hukum positif berupa peraturan perundang-undangan. Legislasi pada dasarnya dapat digambarkan sebagai sebuah proses panjang yang mencakup berbagai tahapan yang diawali dari tahap perencanaan pembuatan hukum, penyusunan, formulasi, pembahasan, pengesahan, pengundangan, hingga sosialisasi produk hukum. Apabila dikaji secara etimologis, istilah teori legislasi diadaptasi dari berbagai terjemahan bahasa-bahasa negara lain, salah satunya seperti dalam bahasa Inggris teori legislasi disebut dengan legislation of theory, sedangkan dalam bahasa Belanda disebut theorie van de wetgeving yang diartikan sebagai teori membuat atau menyusun undangundang, dan selanjutnya di Jerman disebut dengan theorie der gesetzgebug. ${ }^{23}$ Secara terminologi, teori legislasi dapat diartikan sebagai teori yang mengkaji dan menganalisis cara dan teknik pembentukan peraturan perundang-undangan dimulai dari tahap perencanaan, penyusunan, pembahasan, pengesahan atau penetapan, dan pengundangan. Berdasarkan konsepsi definitif teori legislasi, maka diambil sebuah konklusi bahwa teori legislasi dapat disamakan dengan proses penyusunan peraturan perundangundangan yang dimulai dari tahap perencanaan sampai dengan pengundangannya. ${ }^{24}$

Teori legislasi pertama kali dikembangkan oleh Jean Jacques Rousseau yang mengemukakan metode pembuatan hukum yang mencerminkan kehendak umum. Pada masa selanjutnya teori legislasi dikembangkan oleh Hans Kelsen yang

22 Anis Ibrahim, Legislasi Dalam Perspektif Demokrasi: Analisis Interaksi Politik dan Hukum dalam Proses Pembentukan Peraturan Daerah di Jawa Timur. (Disertasi, Semarang: UNDIP, 2008), hlm. 114

23 Salim HS, Penerapan Teori Hukum Pada Penelitian Tesis dan Disertasi, (Jakarta: PT. RajaGrafindo Persada, 2017), hlm. 33

24 Ibid, hlm. 36 
memperkenalkan Stufenbau Theorie yang menyatakan bahwa norma hukum pada dasarnya berjenjangjenjang dan berlapis-lapis dalam suatu hierarki (tata susunan). Norma yang lebih rendah berlaku, bersumber dan berdasar pada norma yang lebih tinggi, norma yang lebih tinggi berlaku, bersumber dan berdasar pada norma yang lebih tinggi lagi, demikian seterusnya sampai pada suatu norma yang tidak dapat ditelusuri lebih lanjut dan bersifat hipotesis dan fiktif, yakni Norma Dasar (Grundnorm). ${ }^{25}$ Teori hukum berjenjang yang dikemukakan oleh Hans Kelsen dapat disajikan dalam bentuk piramida sebagai berikut:

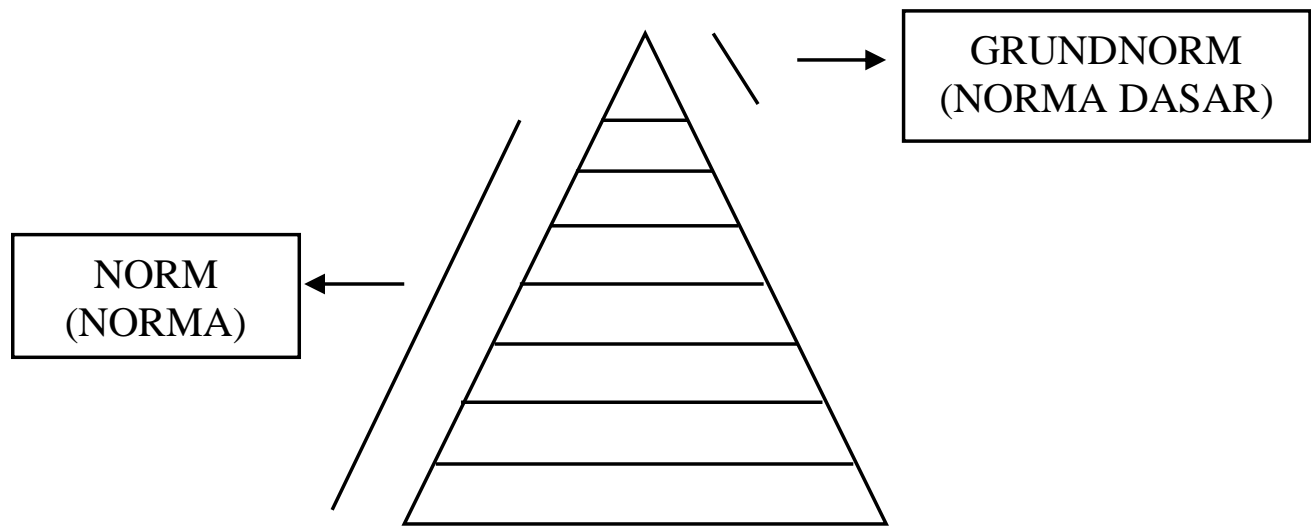

Gambar 1: Stufenbau Theorie oleh Hans Kelsen

Pemikiran Hans Kelsen selanjutnya dikembangkan oleh Hans Nawiasky dalam bukunya yang berjudul Allgemeine Rechtslehre. Dalam bukunya, Hans Nawiasky mengemukakan bahwa ia sependapat dengan teori Hans Kelsen yang menyatakan bahwa norma hukum dari negara manapun selalu berlapis-lapis dan berjenjang-jenjang, namun Hans Nawiasky menambahkan bahwa selain itu norma hukum dari suatu negara juga berkelompok-kelompok dan pengelompokan norma hukum dibagi atas empat kelompok besar ${ }^{26}$ sebagaimana digambarkan dalam piramida di bawah ini:

25 Hans Kelsen, General Theory of Law and State, (New York: Russekk \& Russell, 1945), pg. 113

26 Maria Farida Indrati Soeprapto, Ilmu Perundang-Undangan I, (Jakarta: Kanisius, 2013), hlm. 44 


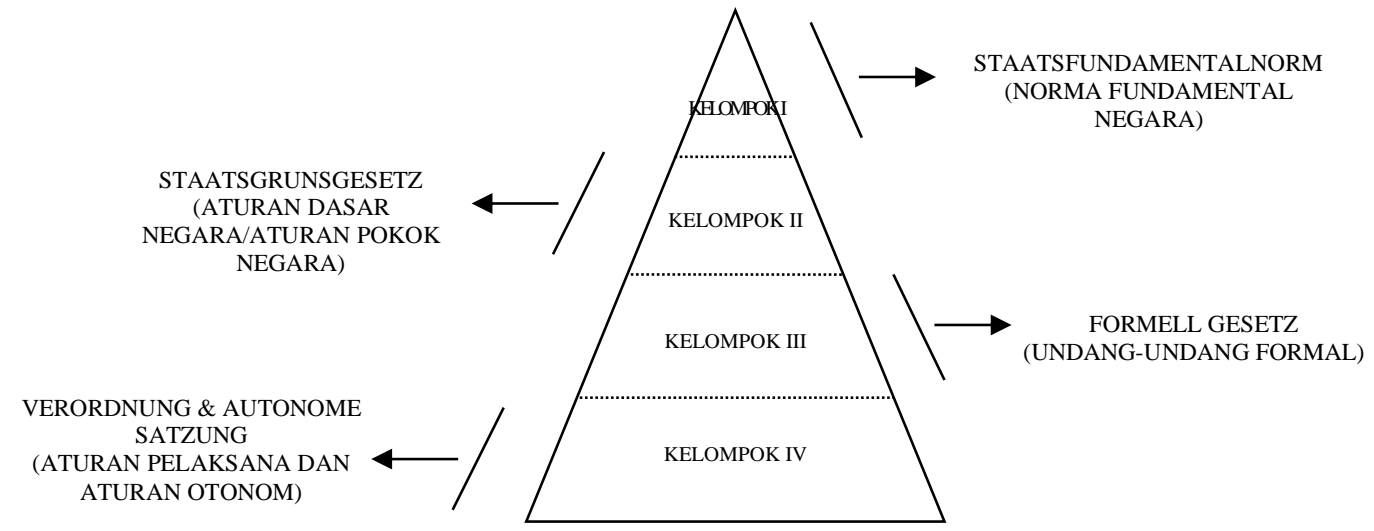

\section{Gambar 2: Teori Kelompok Norma Hukum oleh Hans Nawiasky}

Hierarki norma hukum di Hans Kelsen dan Hans Nawiasky Indonesia pada dasarnya merupakan sebagaimana digambarkan Maria cerminan dari perkembangan teori Farida Indrati Soeprapto ${ }^{27}$ dalam jenjang hukum dan teori kelompok piramida berikut:

norma hukum yang dikemukakan oleh

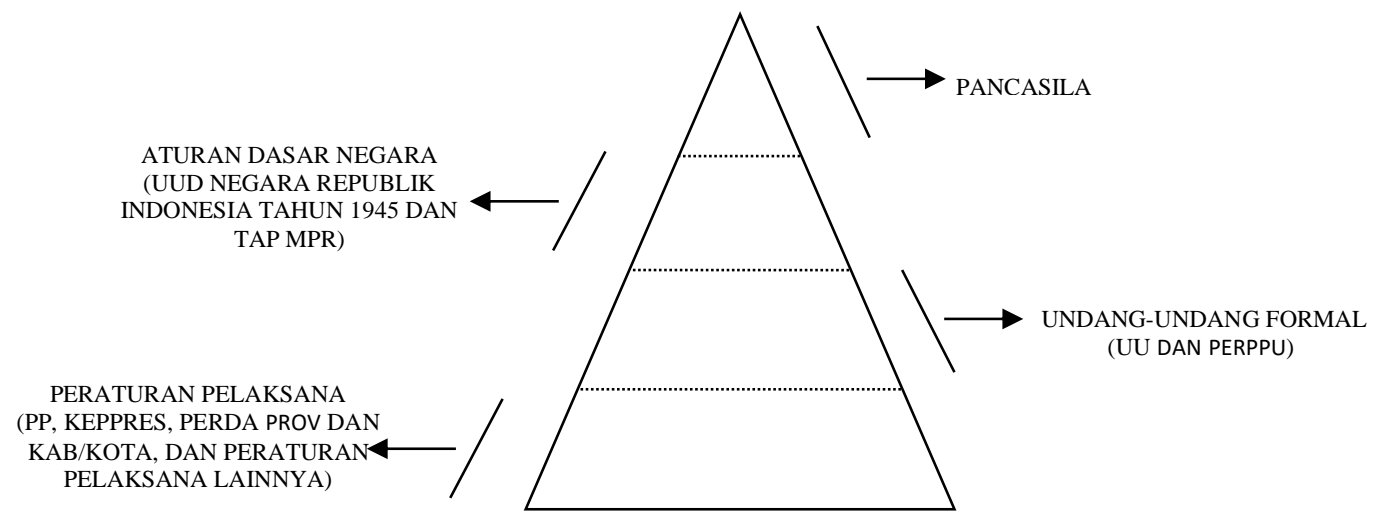

\section{Gambar 3: Adaptasi Teori Norma Hukum di Indonesia} oleh Maria Farida Indrati Soeprapto

$\begin{array}{lll}\text { Dalam pembentukan suatu } & \text { hierarki peraturan perundang- } \\ \text { peraturan perundang-undangan, hal } & \text { undangan adalah asas-asas hukum } \\ \text { lain yang perlu diperhatikan selain } & \text { khusus dalam suatu peraturan }\end{array}$

27 Ibid., hlm. 68 
perundangan-undangan, antara lain:

a. Asas Ignorantia Legis Excusat Neminem (setiap orang dianggap telah mengetahui undang-undang setelah diundangkan dalam Lembaran Negara)

Dalam hal suatu undang-undang telah diundangkan dalam Lembaran Negara, maka undangundang itu berlaku kepada setiap orang tanpa memandang apakah orang tersebut mengetahui atau tidak bahwa undang-undang tersebut telah diundangkan dalam Lembaran Negara.

b. Asas Non Retroaktif (suatu undang-undang tidak boleh berlaku surut)

Suatu undang-undang yang telah diundangkan tidak boleh berlaku surut, dalam artian tidak boleh diberlakukan kepada perbuatan yang telah terjadi sebelum diberlakukannya undang-undang baru tersebut.

c. Lex Spesialis Derogat Lex Generalis (undang-undang yang bersifat khusus mengesampingkan undang-undang yang bersifat umum)
Undang-undang yang mengatur substansi suatu hal secara lebih khusus merupakan undangundang yang lebih tepat untuk dipergunakan daripada undangundangan yang hanya mengatur hal tersebut secara umum.

d. Lex Posteriori Derogate Legi Priori (undang-undang yang lama dinyatakan tidak berlaku apabila ada undang-undang yang baru yang mengatur hal yang sama)

Dalam hal terdapat undangundang baru yang mengatur suatu permasalahan yang sama dengan suatu undang-undang lama, maka ketentuan undang-undang lama tidak berlaku dan yang dipergunakan adalah undangundang yang baru.

e. Lex Superior Derogate Legi Inforiori (hukum yang lebih tinggi derajatnya mengesampingkan hukum/peraturan yang derajatnya dibawahnya)

Dalam hal terdapat suatu permasalahan yang diatur dalam 2 (dua) peraturan perundangundangan yang berbeda, maka yang dipergunakan adalah 
peraturan perundang-undangan yang tingkatannya lebih tinggi dengan memperhatikan ketentuan Pasal 7 Undang-Undang Nomor 12 Tahun 2011 tentang Pembentukan Peraturan Perundang-Undangan yang mengatur secara jelas hierarki perundang-undangan di Indonesia. ${ }^{28}$

Dalam bidang perwalian, terdapat beberapa peraturan perundangundangan yang tersusun secara hierarkis dan mengatur tentang perwalian, antara lain:

\section{a. Kitab Undang-Undang Hukum}

\section{Perdata (KUHPerdata)}

KUHPerdata merupakan aturan
hukum yang notabene dapat
dianggap sebagai warisan
peninggalan kolonial Belanda yang
sampai sekarang masih
dipergunakan di Indonesia untuk
mengatur urusan-urusankeperdata-
an, termasuk mengatur urusan
perwalian. Di dalam KUHPerdata
pengaturan hukum tentang
perwalian terdapat dalam Buku
Kesatu tentang Orang, Bab XV,

Bagian Kedua sampai dengan Bagian Ketiga Belas, mulai Pasal 331 sampai dengan Pasal 418a.

Pasal 331 sampai dengan Pasal 339 mengatur tentang perwalian pada umumnya. Pasal 340 sampai dengan Pasal 344 mengatur tentang ketentuan tempat tinggal bagi penanggung, penghapusan hipotek, dan penetapan Pengadilan Negeri tentang ketentuan di bagian kedua diambil melalui surat permintaan. Pasal 345 sampai dengan Pasal 354a mengatur tentang perwalian oleh Ayah atau Ibu dalam hal salah satu orang tua meninggal dunia. Pasal 355 sampai dengan Pasal 358 mengatur tentang perwalian yang diperintahkan oleh Ayah atau Ibu kepada seorang wali setelah Ayah atau Ibu tersebut meninggal dunia. Pasal 359 sampai dengan Pasal 364 mengatur tentang perwalian yang diperintahkan oleh Pengadilan Negeri. Pasal 365 dan Pasal 365a mengatur tentang perwalian oleh perkumpulan, yayasan, dan lembaga sosial. Pasal 366 sampai

28 H. Zaeni Asyhadie dan Arief Rahman, Pengantar Ilmu Hukum, (Jakarta: Raja Grafindo Persada, 2013), hlm. 135-136 
dengan Pasal 375 tentang ketentuan pengawasan terhadap wali yang banyak melibatkan Balai Harta Peninggalan selaku wali pengawas yang berperan melindungi hak-hak keperdataan anak yang berada di bawah perwalian. Pasal 376 sampai dengan Pasal 378 mengatur tentang alasan-alasan yang dapat melepaskan diri dari perwalian. Pasal 379 sampai dengan Pasal 382g mengatur tentang pengecualian, pembebasan, dan pemecatan dari perwalian. Pasal 383 sampai dengan Pasal 384 mengatur tentang pengawasan wali terhadap pribadi anak yang berada di bawah perwalian. Pasal 385 sampai dengan Pasal 408 mengatur tentang tugas pengurusan wali. Pasal 409 sampai dengan Pasal 414 mengatur tentang perhitungan pertanggungjawaban perwalian. Pasal 415 sampai dengan Pasal 418a mengatur tentang Balai Harta Peninggalan dan Dewan Perwalian.

Berdasarkan pasal-pasal mengenai perwalian yang terdapat di dalam KUHPerdata, dapat ditarik sebuah pemahaman bahwa
KUHPerdata dapat disebut sebagai acuan dasar dalam pelaksanaan tugas-tugas Balai Harta Peninggalan sebagai wali pengawas, karena KUHPerdata mengatur permasalahan tentang perwalian secara komprehensif mulai dari ketentuan umum hingga urusan teknis pelaksanaan perwalian.

\section{b. Undang-Undang Nomor 1 Tahun}

\section{4 tentang Perkawinan}

Undang-Undang Nomor 1 Tahun 1974 tentang Perkawinan (selanjutnya disebut UndangUndang Perkawinan) merupakan produk hukum yang awalnya dibentuk dengan tujuan untuk menyeragamkan(mengunifikasikan) aturan hukum di Indonesia tentang Perkawinan. Undang-Undang Perkawinan banyak mengadaptasi konsep-konsep hukum Islam, sehingga pada saat mengimplementasikan Undang-Undang Perkawinan di tengah-tengah masyarakat Indonesia yang sarat akan kebhinekaan, undang-undang ini sulit untuk mewujudkan cita-cita unifikasi hukum perkawinan di Indonesia, sehingga ketentuan 


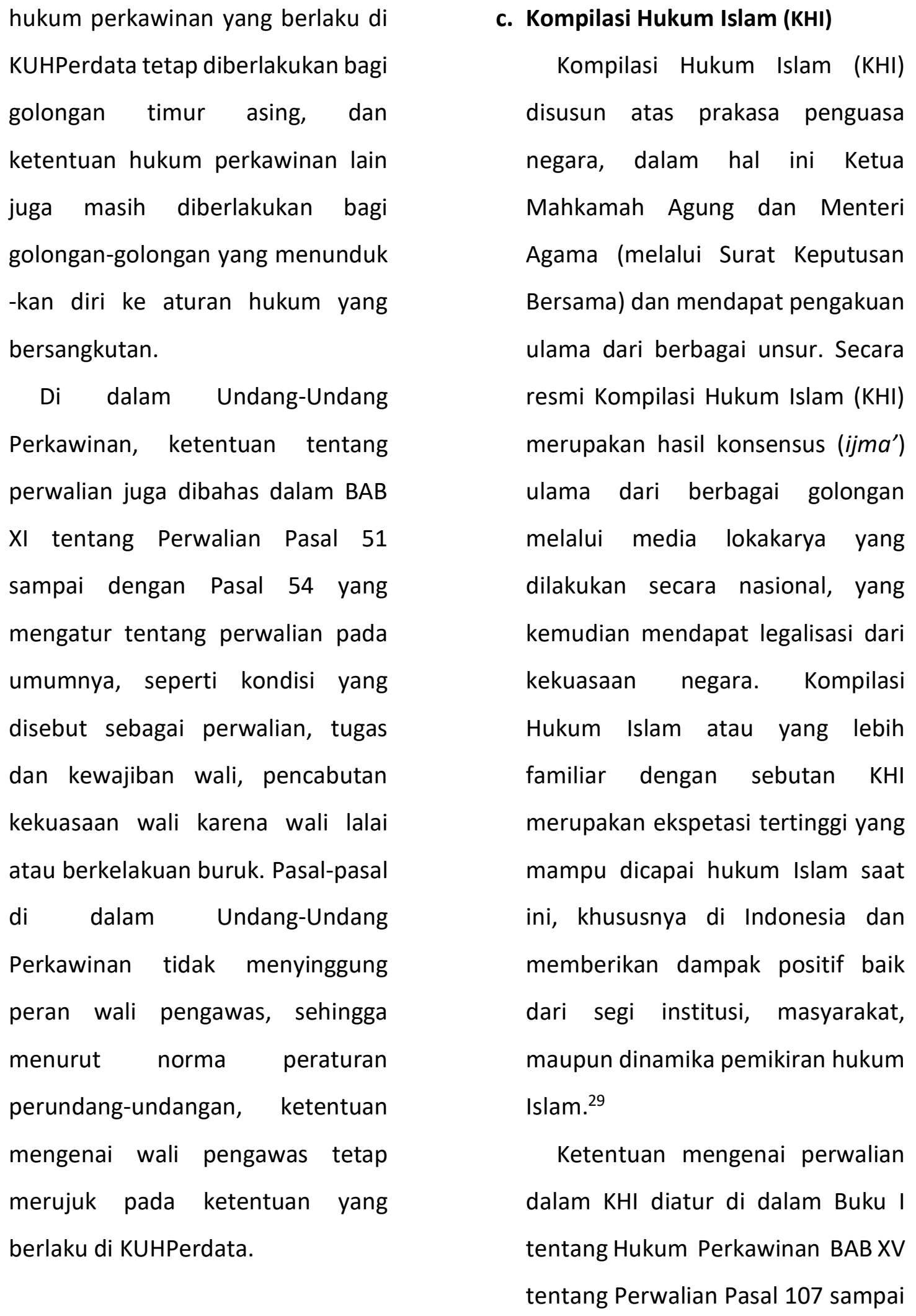

29 Hikmatullah, Selayang Pandang Sejarah Penyusunan Kompilasi Hukum Islam Di Indonesia, Jurnal AJUDIKASI, Vol. 1 No 2, Desember (2017): 45 
dengan Pasal 112 yang mengatur tentang konsep perwalian dalam Islam pada umumnya. KHI pada dasarnya tidak menyinggung Balai Harta Peninggalan sebagai wali pengawas. $\mathrm{KHI}$ menjadi dasar bagi aturan hukum Islam khusus lainnya, seperti Qanun Nomor 11 Tahun 2008 tentang Perlindungan Anak untuk melainkan melibatkan sebuah lembaga lain, yakni Baitul Mal untuk mengurusi harta-harta kekayaan anak yang berada di bawah perwalian. Selain itu, terdapat pula Perppu Nomor 2 Tahun 2007 tentang Penanganan Permasalahan Hukum dalam Rangka Pelaksanaan Rehabilitasi dan Rekonstruksi Wilayah dan Kehidupan Masyarakat di Provinsi Nanggroe Aceh Darussalam dan Kepulauan Provinsi Sumatera Utara yang mengatur dengan tegas bahwa Baitul Mal merupakan pengelola harta (termasuk harta anak yang berada di bawah perwalian) untuk kaum muslim, sedangkan Balai Harta Peninggalan merupakan pengelola harta untuk kaum non muslim. ${ }^{30}$

d. Undang-Undang Nomor 23 Tahun 2002 sebagaimana telah diubah terakhir dengan Undang-Undang Nomor 35 Tahun 2014 tentang Perlindungan Anak

Undang-Undang Perlindungan Anak pada dasarnya dibentuk untuk menjamin perlindungan terhadap hak dan kesejahteraan anak. Di dalam Undang-Undang Perlindungan Anak yang lama, yakni UndangUndang Nomor 23 Tahun 2002, ketentuan tentang Perwalian terdapat dalam Pasal 33 sampai dengan Pasal 36 yang mengatur tentang penunjukan wali dan Balai Harta Peninggalan selaku wali pengawas untuk mewakili kepentingan dan pengurusan harta anak, serta mengatur mengenai pencabutan perwalian. Sedangkan dalam Undang-Undang Perlindungan Anak yang baru, yakni UndangUndang Nomor 35 Tahun 2014, tidak dapat ditemukan ketentuan tentang Perwalian karena undangundang yang bersangkutan

30 Zahratul Idami, Tanggung Jawab Wali Terhadap Anak Yang Berada di Bawah Perwaliannya (Suatu Penelitian di Kota Banda Aceh), Jurnal Dinamika Hukum, Vol. 12, No. 1, Januari (2012: 66 
merupakan undang-undang revisi yang hanya mengubah sebagian pasal yang terdapat di undangundang lama, sehingga ketentuan perwalian di Undang-Undang Perlindungan Anak merujuk pada pasal-pasal yang terdapat di Undang-Undang Perlindungan Anak sebelum revisi, yakni UndangUndang Nomor 23 Tahun 2002.

e. Peraturan Pemerintah Nomor 29 Tahun 2019 tentang Syarat dan Tata Cara Penunjukan Wali

Peraturan Pemerintah Nomor 29 Tahun 2019 tentang Syarat dan Tata Cara Penunjukan Wali mengatur ketentuan-ketentuan tentang perwalian secara komprehensif, akan tetapi untuk urusan pengawasan wali, Peraturan Pemerintah ini seolah mengenyampingkan Balai Harta Peninggalan yang berdasarkan KUHPerdata bertindak sebagai wali pengawas. Balai Harta Peninggalan hanya disinggung secara eksplisit di Pasal 13 yang mengatur bahwa salinan penetapan Pengadilan Negeri harus disampaikan salah satunya kepada instansi pemerintah pusat atau unit kerja di lingkungan instansi pemerintah pusat yang menyelenggarakan urusan pemerintahan di bidang harta peninggalan setempat.

Pengikisan eksistensi Balai Harta Peninggalan terlihat jelas dalam Pasal 26 yang mengatur tentang pengawasan perwalian dilakukan oleh kementerian yang menyelenggarakan urusan di bidang sosial, yakni Kementerian Sosial. Perpindahan kewenangan pengawasan perwalian ke Kementerian Sosial tentunya menyalahi asas pembentukan peraturan perundang-undangan. KUHPerdata yang notabene lebih tinggi kedudukannya daripada Peraturan Pemerintah dasarnya telah diabaikan. Tidak dicantumkannya Balai Harta Peninggalan sebagai wali pengawas dalam Peraturan Pemerintah tentang Syarat dan Tata Cara Penunjukan Wali merupakan bentuk pertentangan antara undangundang yang lebih tinggi dengan undang-undang yang lebih rendah Apabila merujuk pada asas Lex 
Superior Derogate Legi Inforiori

(hukum yang lebih tinggi derajatnya mengesampingkan hukum/ peraturan yang derajatnya dibawahnya), maka sebenarnya tidak ada masalah karena ketentuan hukum mengenai pengawasan terhadap wali tetap ada pada Balai Harta Peninggalan karena KUHPerdata memiliki hierarki yang lebih tinggi daripada Peraturan

Pemerintah. Ketentuan dalam

Peraturan Pemerintah tentang

Syarat dan Tata Cara Penunjukan

Wali yang menyatakan bahwa

pengawasan perwalian ditangani oleh Kementerian Sosial secara otomatis dikesampingkan dengan aturan hukum yang lebih tinggi, yakni KUHPerdata yang mengatur bahwa yang memegang tugas sebagai wali pengawas adalah Balai Harta Peninggalan.

Berdasarkan berbagai ketentuan peraturan perundang-undangan yang mengatur tentang perwalian yang telah diuraikan di atas, penulis menyajikan analisa dalam bentuk tabel mengenai eksistensi Balai Harta Peninggalan dalam berbagai peraturan hukum di bidang perwalian, yakni sebagai berikut:

\section{Tabel 1: Analisa Perbandingan Eksistensi Balai Harta Peninggalan Dalam Berbagai Peraturan Hukum di Bidang Perwalian}

\begin{tabular}{|c|l|l|}
\hline No. & Peraturan Perundang-Undangan & \multicolumn{1}{|c|}{ Eksistensi Balai Harta Peninggalan } \\
\hline 1. & $\begin{array}{l}\text { Kitab Undang-Undang Hukum } \\
\text { Perdata (KUHPerdata) }\end{array}$ & $\begin{array}{l}\text { Balai Harta Peninggalan memiliki kedudukan yang jelas sebagai wali } \\
\text { pengawas dalam perwalian, dimana tugas dan kewenangannya } \\
\text { diatur dengan jelas dalam pasal-pasal tentang perwalian yang } \\
\text { terdapat di dalam KUHPerdata }\end{array}$ \\
\hline 2. & $\begin{array}{l}\text { Undang-Undang Nomor 1 Tahun } \\
1974 \text { tentang Perkawinan }\end{array}$ & $\begin{array}{l}\text { Tidak terdapat ketentuan tentang Balai Harta Peninggalan sebagai } \\
\text { wali pengawas, sehingga ketentuan wali pengawas tetap merujuk } \\
\text { pada ketentuan di dalam KUHPerdata yang secara tegas mengatur } \\
\text { bahwa Balai Harta Peninggalan berperan sebagai wali pengawas } \\
\text { dalam perwalian }\end{array}$ \\
\hline 3. & Kompilasi Hukum Islam (KHI) & $\begin{array}{l}\text { Kompilasi Hukum Islam menjadi salah satu penyebab berkurangnya } \\
\text { eksistensi Balai Harta Peninggalan khususnya di daerah-daerah } \\
\text { istimewa yang memberlakukan hukum Islam, karena KHI } \\
\text { memperkenalkan konsep instansi Baitul Mal sebagai lembaga yang } \\
\text { mengelola harta-harta penduduk muslim, sehingga Balai Harta } \\
\text { Peninggalan hanya mengelola harta-harta penduduk non muslim }\end{array}$ \\
\hline
\end{tabular}


(Lanjutan Tabel 1 No. 4 dan 5)

\begin{tabular}{|c|l|l|}
\hline No. & Peraturan Perundang-Undangan & \multicolumn{1}{c|}{ Eksistensi Balai Harta Peninggalan } \\
\hline 4. & $\begin{array}{l}\text { Undang-Undang Nomor 23 Tahun } \\
\text { 2002 sebagaimana telah diubah } \\
\text { terakhir dengan Undang-Undang } \\
\text { Nomor 35 Tahun 2014 tentang } \\
\text { Perlindungan Anak }\end{array}$ & $\begin{array}{l}\text { Dalam Undang-Undang Nomor 23 Tahun 2002 tentang Perlindungan } \\
\text { Anak, Balai Harta Peninggalan diberikan kewenangan sebagai wali } \\
\text { pengawas sebagaimana dengan ketentuan yang terdapat dalam } \\
\text { KUHPerdata, sedangkan dalam undang-undang revisinya, yakni } \\
\text { Undang-Undang Nomor 35 Tahun 2014, Balai Harta tidak disinggung } \\
\text { sehingga ketentuan tentang wali pengawas tetap merujuk pada } \\
\text { KUHPerdata dan Undang-Undang Perlindungan Anak yang lama }\end{array}$ \\
\hline 5. & $\begin{array}{l}\text { Peraturan Pemerintah Nomor 29 } \\
\text { Tahun 2019 tentang Syarat dan } \\
\text { Tata Cara Penunjukan Wali }\end{array}$ & $\begin{array}{l}\text { Dalam Peraturan Pemerintah ini, Balai Harta Peninggalan seolah } \\
\text { dikesampingkan dalam hal pengawasan terhadap wali. Kewenangan } \\
\text { Balai Harta Peninggalan sebagai wali pengawas secara tidak } \\
\text { langsung telah berpindah ke kementerian yang menyelenggarakan } \\
\text { urusan pemerintahan di bidang sosial }\end{array}$ \\
\hline
\end{tabular}

Berdasarkan perbandingan materi muatan berbagai peraturan perundang-undangan di bidang perwalian, diketahui bahwa terdapat disharmonisasi, overlapping (tumpang tindih) ketentuan peraturan, serta penyimpangan-penyimpangan lain yang terjadi di antara peraturan perundang-undangan yang satu dengan peraturan perundangundangan yang lain, sehingga hal ini tentunya akan menyebabkan hak-hak anak yang berada di bawah perwalian menjadi kurang jelas karena tidak jelasnya ketentuan hukum tentang wali pengawas, selain itu disharmonisasi tersebut cepat atau lambat akan menyebabkan kemunduran dalam perkembangan hukum di Indonesia.

\section{Penutup}

Ketentuan hukum tentang wali pengawas dijabarkan secara umum dalam pasal-pasal di KUHPerdata, khususnya dalam pasal yang menjabarkan tentang perwalian, akan tetapi terdapat disharmonisasi dalam berbagai peraturan perundang-undangan lain yang memuat substansi tentang perwalian. Di dalam Undang-Undang Nomor 23 Tahun 2002 tentang Perlindungan Anak, Balai Harta Peninggalan selaku Wali Pengawas hanya disebutkan dalam 1 pasal, yakni Pasal 35 Undang-Undang Perlindungan Anak, sedangkan dalam Undang-Undang Nomor 35 Tahun 2014 tentang Perubahan Kedua Atas Undang-Undang Nomor 23 Tahun 2002 tentang Perlindungan Anak, Balai Harta Peninggalan bahkan tidak disinggung 
sama sekali. Kemudian lahir Peraturan Pemerintah Nomor 29 Tahun 2019 tentang Syarat dan Tata Cara Penunjukan Wali yang menjabarkan bahwa pengawasan terhadap wali dan urusan perwalian dilakukan oleh pemerintah yang menyelenggarakan urusan sosial, sehingga secara tidak langsung menghilangkan dan bahkan mengganti pihak yang berkewenangan sebagai wali pengawas yang semula adalah Balai Harta Peninggalan, menjadi dinas sosial.

Harmonisasi peraturan perundangundangan di Indonesia, khususnya di bidang perwalian sangat penting untuk mempertegas peran Balai Harta Peninggalan selaku wali pengawas agar hak-hak keperdataan anak yang berada di bawah perwalian dapat terjamin. Selain itu, harmonisasi peraturan perundangundangan di bidang perwalian melalui sinkronisasi teori legislasi dan asas pembentukan peraturan perundangundangan juga memiliki peran penting untuk mewujudkan suatu rekonstruksi pemikiran mengenai urgensitas dan bentuk eksistensi Balai Harta Peninggalan dalam menjamin kesejahteraan dan melindungi hak-hak keperdataan anak yang berada di bawah perwalian.

Sampai saat ini, peraturan perundangundangan di bidang perwalian dapat dinilai belum harmonis karena antara peraturan yang satu dengan peraturan yang lainnya terdapat tumpang tindih (overlapping) pengaturan materi muatan tentang eksistensi Balai Harta Peninggalan selaku wali pengawas, sehingga perlu dilakukan revisi pada peraturan perundang-undangan yang mengikis eksistensi dan peran Balai Harta Peninggalan selaku wali pengawas. Revisi peraturan perundang-undangan harus dilakukan dengan melalui proses harmonisasi materi muatan peraturan perundang-undangan yang mengatur tentang perwalian pada saat pembuatan naskah akademik peraturan perundangundangan penggantinya, agar ke depannya terjadi rekonstruksi eksistensi Balai Harta Peninggalan selaku wali pengawas sehingga Balai Harta Peninggalan dapat dengan mudah menjalankan tugas dan fungsinya sebagai wali pengawas untuk menjamin hak-hak keperdataan dan kesejahteraan anak yang berada di bawah perwalian. 


\section{DAFTAR PUSTAKA}

\section{A. Buku}

Asean Law Association, Indonesian Legal System, Editor: Hikmahanto Juwana, et.al., (Philippines: Asean Law Association, 2005).

Asyhadie, H. Zaeni dan Arief Rahman, Pengantar Ilmu Hukum, Jakarta: PT. Raja Grafindo Persada, 2013).

HS, Salim, Penerapan Teori Hukum Pada Penelitian Tesis dan Disertasi, (Jakarta: PT. RajaGrafindo Persada, 2017).

Kelsen, Hans, General Theory of Law and State, (New York: Russekk \& Russell, 1945).

Prawidohamidjojo, R. Soetojo dan Marthalena Pohan, Hukum Orang dan Keluarga (Personen en Familie-Recht), (Surabaya: Airlangga University Press, 2008).

Soeprapto, Maria Farida Indrarti, Ilmu Perundang-undangan 2, (Yogyakarta: Kanisius, 2007).

Soeprapto, Maria Farida Indrati, Ilmu Perundang-Undangan I, (Jakarta: Kanisius, 2013).

Subekti, R., Pokok-Pokok Hukum Perdata, (Jakarta: Intermasa, 2013).

Summa, Muhammad Amin, Hukum Keluarga Islam Dikeluarga Islam, (Jakarta: PT Raja Grafindo, 2001).

Waluyo, Bambang, Penelitian Hukum Dalam Praktek, (Jakarta: Sinar Grafika, 2002).

Yuniagara, Riki, Jenis dan Hirarki Peraturan Perundang-Undangan Indonesia Dalam Lintas Sejarah (TAP MPR dari Masa ke Masa), (Aceh: Unknown, 2013).

\section{B. Artikel Ilmiah}

Attamimi, A. Hamid S., Peranan Keputusan Presiden Republik Indonesia dalam Penyelenggaraan Pemerintahan Negara: Suatu Studi Analisis Mengenai Keputusan Presiden yang Berfungsi Pengaturan dalam Kurun Waktu Pelita IPelita IV, Disertasi IImu Hukum Fakultas Pascasarjana Universitas Indonesia, Jakarta (1990).

Djumati, Penentuan Hak Perwalian Anak Akibat Perceraian Menurut Undang-Undang Nomor 1 Tahun 1974 Tentang Perkawinan. Jurnal Lex Privatum Vol. VI/No. 4/Jun/2018 (2018).

Heriyani, Endang dan Prihati Yuniarlin, Fungsi BHP Sebagai Wali Pengawas Terhadap Anak Di Bawah Perwalian Dalam Rangka Perlindungan Anak, Jurnal Media Hukum, Volume 22 No. 2 (2015).

Hikmatullah, Selayang Pandang Sejarah Penyusunan Kompilasi Hukum Islam Di Indonesia, Jurnal AJUDIKASI, Vol. 1 No 2 (2017). 
Ibrahim, Anis, Legislasi Dalam Perspektif Demokrasi: Analisis Interaksi Politik dan Hukum dalam Proses Pembentukan Peraturan Daerah di Jawa Timur. Program Doktor Ilmu Hukum UNDIP, Semarang (2008).

Idami, Zahratul, Tanggung Jawab Wali Terhadap Anak Yang Berada di Bawah Perwaliannya (Suatu Penelitian di Kota Banda Aceh), Jurnal Dinamika Hukum, Vol. 12, No. 1 (2012).

Pratiwi, Yulita Dwi, Harmonisasi Perlindungan Harta Kekayaan Anak dalam Perwalian melalui Penguatan Peran Wali Pengawas, Jurnal Suara Hukum Volume 1 Nomor 1 (2019).

Putranto, Nurhendro, Balai Harta Peninggalan Fungsi dan Tugas Pokoknya, Jurnal Ilmiah Balai Harta Peninggalan Surabaya (2013).

Simatupang, Taufik H., Eksistensi dan Efektivitas Pelaksanaan Tugas Balai Harta Peninggalan di Indonesia (Existence and Effectiveness of Performance of Probate Court Duties in Indonesia), Jurnal Penelitian Hukum De Jure, ISSN 1410-5632 Vol. 18 No. 3 (2018).

Syuhada, Analisis Hukum Terhadap Kewenangan Balai Harta Peninggalan Dalam Pengelolaan Harta Kekayaan Yang Tidak Diketahui Pemilik dan Ahliwarisnya (Studi di Balai Harta Peninggalan Medan), Tesis, Universitas Sumatera Utara, Medan, (2009)

Veronita, Septy, Hak Perwalian Anak di Bawah Umur yang Beralih pada Neneknya (Analisis kasus Putusan Mahkamah Agung Republik Indonesia Nomor:372K/Pdt/2008, Tesis, Universitas Indonesia, Jakarta (2013).

\section{Peraturan Perundang-Undangan}

Kitab Undang-Undang Hukum Perdata (KUHPerdata)

Undang-Undang Nomor 1 Tahun 1974 tentang Perkawinan Kompilasi Hukum Islam (KHI)

Undang-Undang Nomor 23 Tahun 2002 sebagaimana telah diubah terakhir dengan Undang-Undang Nomor 35 Tahun 2014 tentang Perlindungan Anak

Peraturan Pemerintah Nomor 29 Tahun 2019 tentang Syarat dan Tata Cara Penunjukan Wali 


\section{BIODATA PENULIS}

Shela Natasha, S.H. lahir di Medan, latar belakang pendidikan Sarjana Hukum di Universitas Muhammadiyah Sumatera Utara, Iulusan tahun 2017. Shela merupakan salah satu kader tunas pengayoman tahun 2018 dan saat ini bekerja sebagai Analis Hukum di Balai Harta Peninggalan Medan, salah satu Unit Pelaksana Teknis Kantor Wilayah Kementerian Hukum dan HAM Provinsi Sumatera Utara yang berada di bawah naungan langsung Direktorat Perdata pada Direktorat Jenderal Administrasi Hukum Umum Kementerian Hukum dan HAM RI. Selama kuliah, Shela cukup aktif menulis, salah satunya menulis Artikel Ilmiah pada seleksi kegiatan Debat Konstitusi yang diselenggarakan oleh Mahkamah Konstitusi, Artikel IImiah pada seleksi kegiatan Peradilan Semua yang diselenggarakan Mahkamah Konstitusi, serta menulis beberapa opini pada harian Jurnal Asia. Selain itu Shela juga sempat merancang ToR (Term of References) tentang Ekonomi Pancasila pada Pusat Kajian dan Studi Konstitusi Universitas Muhammadiyah Sumatera Utara. Setelah bekerja Shela tetap aktif dalam menulis dikarenakan pekerjaan sebagai Analis Hukum menuntut Shela untuk tetap aktif menganalisis permasalahan hukum yang tengah hangat terjadi di masyarakat. Selama bekerja Shela juga menulis beberapa opini pada harian Sinar Indonesia Baru. Selain itu, Shela sempat diberikan kesempatan untuk mengisi beberapa halaman Jurnal Majalah Hukum Nasional No. 2 Tahun 2018 dengan jurnal saya yang berjudul "Penghapusan Pasal Penggolongan Penduduk dan Aturan Hukum Dalam Rangka Mewujudkan Unifikasi Hukum”. 